\title{
Our Lady of Cocharcas
}

\section{Emily Engel}

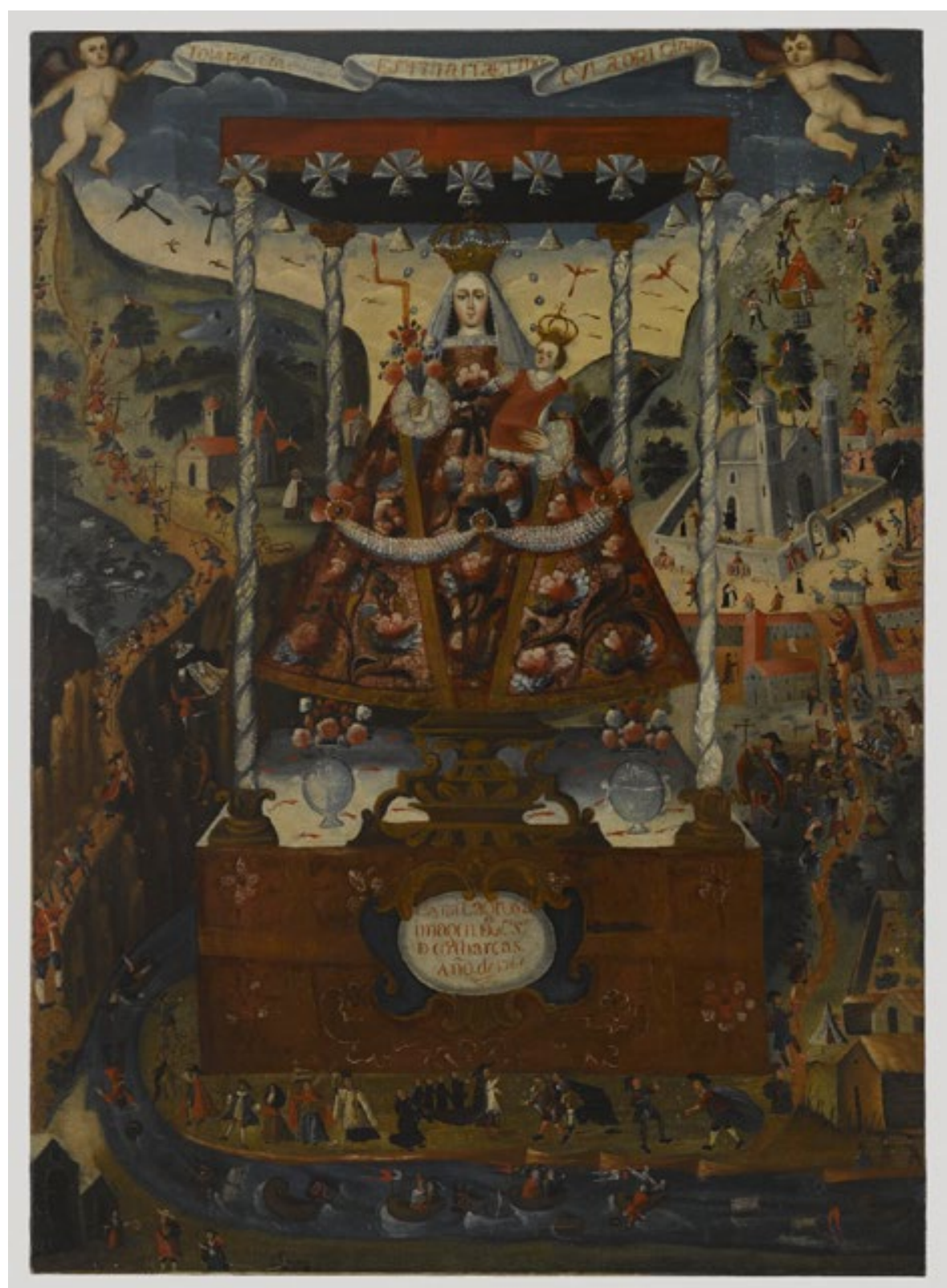

Fig. 1 Cuzco school, Our Lady of Cocharcas Under the Baldachin, 1765

For over four hundred years, pilgrims in the highland Andean province of Apurimac, Peru have prepared offerings, donned colorful woven garments, and set out over treacherous passes to express their allegiance to an advocation of the Virgin Mary known as Our Lady of Cocharcas. ${ }^{1}$ Devotion to Our Lady of Cocharcas began during the Spanish colonial occupation of the region. This unique Peruvian highland cult was grounded in the manipulation of physical bodies during pilgrimage and in other devotional practices centered around the cult statue. ${ }^{2}$ Material objects, including a 
group of documentary paintings of Our Lady of Cocharcas, recall the processes by which ancient Andean pilgrimage traditions became deeply integrated into late-colonial socio-religious consciousness. In the ancient and Inca-occupied Andes, imperial and local sacred sites united diverse geographic areas and dispersed peoples. The AndeanEuropean encounter in Cocharcas produced an environment charged with the tensions of colonial rule. Within this environment, individuals swayed by the ambiguous power of mixed Catholic and Andean ritual practices crafted a communal visual history of local Marian devotion.

During the mid-eighteenth century, large-scale paintings depicting the statue of Our Lady of Cocharcas surrounded by a community of devotees began to appear across Peru. These paintings testify to Cocharcas's expanding renown and significance beyond the regional boundaries of Apurimac. A large vertical oil-on-canvas painting today in the collection of the Brooklyn Museum summarily features the titular sculpture of the Virgin, her highland Andean sanctuary, and the pilgrimage associated with the icon since the sixteenth century (Fig. 1). The painting and others like it were created by indigenous or mestizo Cuzco-school artists. ${ }^{3}$ The artist who created the Brooklyn Museum painting of Our Lady of Cocharcas was likely from the circle of Antonio Vilca, an established cusqueño painter. That such a well-known artist would produce a representation of Our Lady of Cocharcas, which then circulated outside the immediate region of the cult center, demonstrates the significance and reach of the cult during this period. ${ }^{4}$

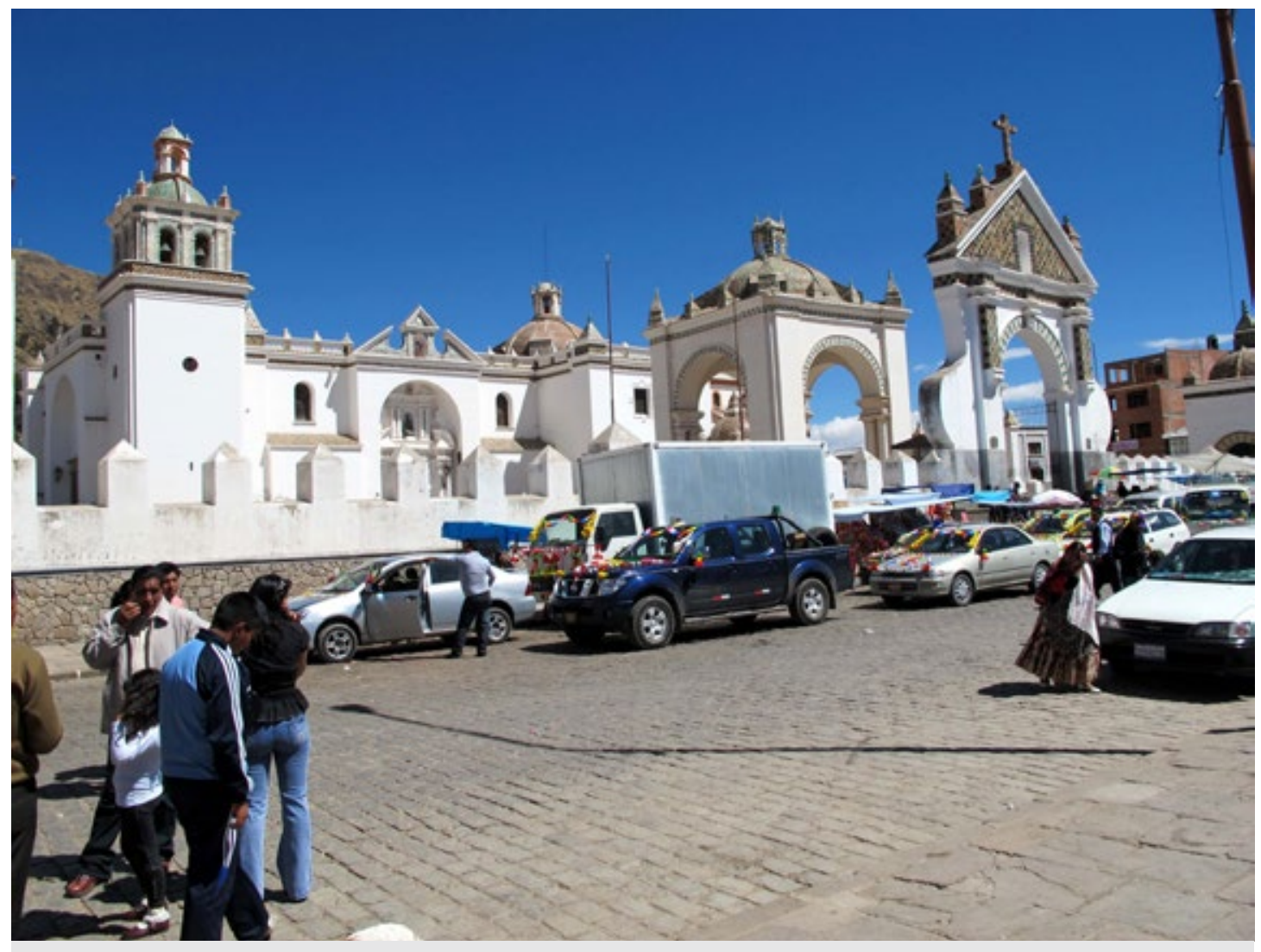

Fig. 2 Francisco Jiménez de Sigüenza, Basilica of Our Lady of Copacabana, Copacabana, Bolivia, ca. 1668-1684 
In 1642, traveling Spanish historian Fernando Montesinos recorded the first written narrative describing the origins and nature of the cult dedicated to the Virgin Mary at Cocharcas. According to his telling, devotion to Our Lady of Cocharcas began in the sixteenth century when Sebastian Martin, an Andean neophyte Christian and resident of the Cocharcas area, suffered an injury and, under the guidance of Jesuit sponsors, undertook a pilgrimage to the shrine of Our Lady of Copacabana on the shores of Lake Titicaca (Fig. 2). ${ }^{5}$ During the arduous journey, Martin's physical ailments were miraculously healed. In response, Martin gratefully dedicated his life to the Virgin Mary and sought to bring her supernatural influence into his home community by transporting a small carved sculptural copy of Our Lady of Copacabana back to Cocharcas in 1598. ${ }^{6}$ Martin and the Jesuits installed Martin's statue in Cocharcas's early-seventeenth-century parish church building and established the devotional community centered around the statue that was later featured in the eighteenth-century paintings. As miracles supported the cult's expansion, pilgrims traveled to the site from points throughout the Viceroyalty of Peru. By the eighteenth century, the Marian statue and shrine at Cocharcas had become the focus of the ritualized pilgrimage and formal processions that figure prominently in the canvas paintings produced at that time.

The Brooklyn Museum painting is opulently detailed with acute attention to the historical and ritual processes that rooted Christianity in the Andean landscape. The painting's composition vibrates with crisp attention to reflective surfaces, energetic patterns, and vivid colors. These details give shape to the dour central icon which stands beneath a tasseled baldachin, flanked by towering mountain peaks in the background. Other Andean Virgins, such as Our Lady of Copacabana and Our Lady of Pomata, are typically depicted perched atop interior altars, floral offerings at their feet, with velvet curtains pulled back at either side to illusionistically reveal the central image (Fig. 3). In contrast, the painter located the statue of Our Lady of Cocharcas in the open air. The festive procession that surrounds her takes place within a precise Andean locale, situated on the banks of the Pampas River. Peripheral landscape and genre scenes team with life, birds take flight over breathtaking Andean peaks, and pilgrims negotiate temptation instigated by horned demons. The painting's iconography endorses the colonial Andean practice of pilgrimage as undertaken by a community that was united around a common belief in the power of place, lineage, history, and shared rituals.

As Vilca and his circle visually indicate, Our Lady of Cocharcas attracted a variety of devotees, from the regional political and religious elites detailed at the base of the processional altar, to the ethnically-mixed highlanders scattered throughout the margins. Although the participants, given their varied ethnic and class backgrounds, would have responded in diverse ways to the colonial Andean divinity, the paintings articulate a unified community of devotees that reinforces group identity through ritual devotion.7 In their depiction of communal pilgrimage, the paintings of Our Lady of Cocharcas visually reiterate the historical journey undertaken by the cult founder. Simultaneously, they emphasize the processes by which central highland communities articulated shared identities, identities grounded in common belief systems and practices that were drawn from both Christian and ancient Andean traditions. Eighteenth-century highlanders regularly engaged in ritual amojonamientos, territorial 


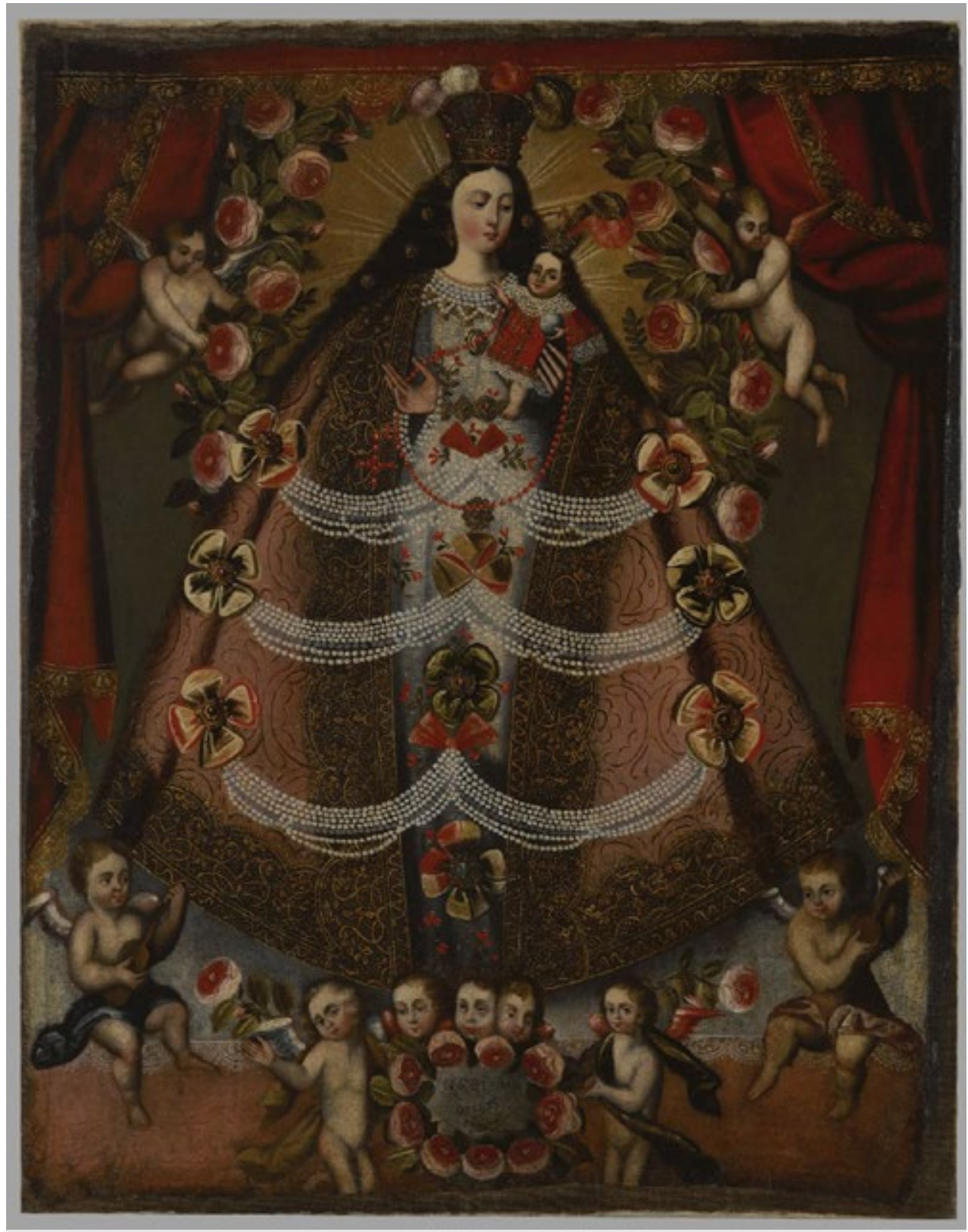

Cuzco school, Our Lady of Pomata, 1675

circumambulations that create and reaffirm sacred and secular boundaries between the land and the people who occupied it. These circumambulations linked revered sites of social memory and articulated local histories by recalling the relationship between community founders and present residents. 8 Performance (pilgrimage, procession, and dance) within this ritualized landscape offered individuals the opportunity to reconnect with their shared history, and to construct pliable community identities based on an evolving worldview. Through ritual practice and the use of material objects imbued with shared sacred meaning, the highland devotees dynamically portrayed in late-colonial paintings of Our Lady of Cocharcas articulated a cohesive regional community.

(C) Emily Engel 


\section{Citation Guide}

1. Emily Engel, "Our Lady of Cocharcas," Object Narrative, in Conversations: An Online Journal of the Center for the Study of Material and Visual Cultures of Religion (2014), doi:10.22332/con.obj.2015.2

Engel, Emily. "Our Lady of Cocharcas." Object Narrative. In Conversations: An Online Journal of the Center for the Study of Material and Visual Cultures of Religion (2014). doi:10.22332/con.obj.2015.2

\section{Notes}

1. This video shows contemporary pilgrims en route to the shrine at Cocharcas: www.youtube.com/watch?v=1Wa3tgEIqK8

2. N. Ross Crumrine and Alan Morinis, "La Peregrinación, The Latin American Pilgrimage," in Pilgrimage in Latin America, ed. N. Ross Crumrine and Alan Morinis (New York: Greenwood Press, 1991).

3. Eleven paintings of Our Lady of Cocharcas have been located to date. See Emily Engel, "Visualizing a Colonial Peruvian Community in the Eighteenth-Century Paintings of Our Lady of Cocharcas," Religion and the Arts 13 (2009). doi:10.1163/156852909x460438

4. Carolyn Dean, "The Renewal of Old World Images and the Creation of Colonial Peruvian Visual Culture," in Converging Cultures, Art and Identity in Spanish America, ed. Diana Fane (Brooklyn: Brooklyn Museum of Art, 1996).

5. Fernando Montesino, Anales del Perú, ed. Victor M. Maurtua (Madrid: Instituto Historico del Peru, 1906).; Ruben Vargas Ugarte, Historia del culto de María en Iberoamérica y de sus imágenes y santuarios más celebrados (Madrid: Talleres Gráficos, 1956). The precise sources for Vargas Ugarte's account are unknown. See also Teresa Gisbert, Iconografía y mitos indígenas en el arte (La Paz: Linea Editorial, Fundacion BHN, 1994) and Verónica Salles-Reese, From Viracocha to the Virgin of Copacabana, Representation of the Sacred at Lake Titicaca (Austin: University of Texas Press, 1997).

6. The modern statue used today and illustrated here replaced the colonial-era sculpture during the twentieth century.

7. Crumrine and Morinis, "La Peregrinación."

8. Thomas A. Abercrombie, Pathways of Memory and Power: Ethnograpy and History Among an Andean People (Madison: University of Wisconsin Press, 1998). 